\title{
Eksperimentasi Model Pembelajaran Problem Based Learning (PBL) Dan Kooperatif Tipe Group Investigation (GI) Pada Materi Peluang Ditinjau Dari Kemandirian Belajar Siswa
}

\author{
Ahmad Faqihi \\ Tenaga Pengajar, Program Studi Manajemen Pelabuhan, Akademi Ilmu Pelayaran Nusa Tenggara, Nusa \\ Tenggara Barat, Indonesia \\ Email: Faqihi@ Aipnusra.Ac.Id
}

\begin{abstract}
The objective of this research was to investigate the effect of the learning models on learning achievement viewed from learning style types of the students. The learning models compared were PBL, GI, and classical with scientific approach model. The type of the research was quasi-experimental research with $3 \times 3$ factorial design. The population of this research was the students in grade X1 higher Secondary School in Lombok East on academic year of $2014 / 2015$. The size of the sample was 282 students, which was taken by using stratified cluster random sampling technique. The instruments used for data collection were learning style questionnaire and mathematics achievement test. The hypothesis test used unbalance two ways analysis of variance. The results of the research were as follows. (1) the problem based learning model (PBL) and the cooperative learning model of the group investgation (GI) type with scientific approach result in equal learning achievement in mathematics, buth both problem based learning model (PBL) and the cooperative learning model of the group investgation (GI) type give better result in learning achievement in mathematics than the classical with scientific approach. (2) the student with the high, medium, and ow independent learning levels have equal learning achievement. (3) in each of the learning models, the high, medium, and, low independent learning levels, result in the equal learning achievement. (4) in each of the independent learning levels, the problem based learning model (PBL) and the cooperative learning model of the group investgation (GI) type with scientific approach result in equal learning achievement in mathematics, buth both problem based learning model (PBL) and the cooperative learning model of the group investgation (GI) type give better result in learning achievement in mathematics than the classical with scientific approach.
\end{abstract}

Keywords: : Learning Model, PBL, GI, Classical Learning Model, Scientific Approach, Independent Learninglevels, Achievement.

\section{PENDAHULUAN}

Matematika mempunyai peran strategis dalam proses pendidikan karena banyak cabang ilmu lain yang memanfaatkan matematika. Dalam pembelajaran di sekolah baik tingkat Sekolah Menengah Pertama (SMP) maupun Sekolah menengah atas (SMA) sering kali matematika dianggap sebagai mata pelajaran yang sulit dipelajari, seperti halnya yang pernah dialami penulis pada saat menempuh sekolah dijenjang SD, SMP dan SMA. Banyak siswa yang merasa terbebani jika harus berhadapan dengan matematika di sekolah. Perasaan terbebani ini disebabkan karena mereka sudah beranggapan bahwa ilmu matematika ini rumit, membingungkan dan banyak yang merasa pesimis dahulu sebelum belajar matematika. Akhirnya siswa hanya menghafal materi pelajaran matematika untuk memenuhi syarat ujian saja. Akibatnya sering terjadi kekeliruan dalam pemahaman konsep dan berdampak prestasi belajar matematika yang dicapai siswa menjadi rendah. Permasalahan seperti ini mengakibatkan rendahnya prestasi belajar matematika. Berdasarkan data dari Badan Standar
Nasional Pendidikan (BSNP, 2013) Rendahnya prestasi belajar siswa pada mata pelajaran matematika juga dialami pada siswa SMA Negeri di Kota Mataram Berdasarkan hasil analisis daya serap siswa pada materi peluang pada nilai Ujian Nasional tahun pelajaran 2012/2013 untuk daerah Kota Selong, diperoleh bahwa daya serap siswa pada materi materi peluang pada tingkat kabupaten sebesar 53,12\%, pada tingkat provinsi $55,36 \%$; pada tingkat nasional $63,35 \%$.

Hal lain terkait kemampuan akademis siswa dalam pelajaran matematika juga menunjukkan hasil yang belum memuaskan. Hal ini ditunjukkan oleh hasil penilaian yang dilakukan oleh sebuah program yang bernama Programme for International Student Assessment (PISA) yaitu sebuah program internasional yang bertujuan untuk mengevaluasi kemampuan membaca, matematika, dan sains, serta bertujuan untuk mengetahui kemampuan anak usia 15 tahun dalam menggunakan kemampuan dan keahlian yang telah mereka pelajari di sekolah 
dalam menjalani kehidupan mereka seharihari pada zaman global yang penuh tantangan. PISA telah melakukan kajian sejak tahun 2000 hingga kini (Stacey, 2011: 95).

pelaksanaan pembelajaran pada kurikulum 2013 berbasis kompetensi dianjurkan juga menggunakan pendekatan andragogi, yang berbeda dengan pedagogi, terutama dalam pandangan terhadap peserta didik. Pedagogi diartikan sebagai "the art and science of teaching children", sedangkan andragogi diartikan sebagai "the art and science of helping adults learn", (Knowles, 1970: Cross, 1981 dalam Mulyasa: 2002)

Sudah seharusnya hasil dari pembelajaran matematika yang dilaksanakan di sekolah selama ini mengacu pada tujuan pembelajaran matematika tersebut. Namun secara umum, fakta di lapangan menunjukkan bahwa pembelajaran di berbagai sekolah, lebih menekankan pada perolehan nilai ulangan dan nilai ujian. Banyak guru yang berpandangan bahwa siswa dikatakan baik kompetensinya apabila nilai hasil ulangan atau hasil ujiannya tinggi (Jamal Ma'mur Asmani, 2011: 22). Menurut Sutarto Hadi (2005: 12), praktik pendidikan yang selama ini berlangsung di sekolah ternyata sangat jauh dari hakikat pendidikan yang sesungguhnya, yaitu pendidikan yang menjadikan siswa sebagai manusia yang memiliki kemampuan belajar untuk mengembangkan potensi dirinya dan mengembangkan pengetahuan lebih lanjut untuk kepentingan dirinya sendiri. Menurut Zamroni (dalam Sutarto Hadi, 2005: 12-13), praktik pendidikan yang demikian mengisolir diri dari lingkungan sekitar dan dunia kerja, serta tidak mampu menjadikan siswa sebagai manusia yang utuh dan berkepribadian.

Untuk mengatasi masalah-masalah tersebut, maka diperlukan suatu pembelajaran yang sesuai, selain pembelajaran tradisional (konvensional). Dalam proses pembelajaran ini tidak lagi siswa menjadi seorang pendengar, tetapi siswa dapat memecahkan masalah dengan sendirinya sesuai dengan kecakapan yang siswa miliki untuk berpikir kritis dalam menghadapi masalah serta siswa menerima ataupun menemukan dan menggali sendiri pemecahan masalah pada pelajaran Matematika. Pembelajaran yang sesuai dengan yang dimaksud adalah Problem Based Learning (PBL) dan Pembelajaran Kooperatif tipe Group Investigation (GI).

Dalam pembelajaran berbasis masalah tugas guru adalah memberikan kemudahan belajar kepada peserta didik, dengan menyediakan berbagai sarana dan sumber belajar yang memadai. Guru bukan hanya menyampaikan meteri pembelajaran yang berupa hapalan, tetapi mengatur lingkungan dan strategi pembelajaran yang memungkinkan peserta didik belajar. Lingkungan belajar yang kondusif sangat penting dan sangat menunjang pembelajaran kontekstual dan keberhasilan pembelajaran keseluruhan.

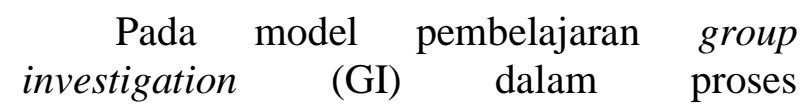
pembelajarannya melibatkan siswa sejak dari perencanaan, baik dalam menentukan topik maupun cara untuk mempelajarinya melalui investigasi. Sehingga model pembelajaran ini menuntut keaktifan dari siswa sebagai subjek sekaligus objek pendidikan dan pengajaran. Siswa tidak hanya sebagai objek diam tanpa ada upaya dari diri sendiri untuk bagaimana seharusnya dia belajar, bukan bagaimana menulis pelajaran matematika. Selain itu GI menuntut siswa untuk memiliki kemampuan yang baik dalam berkomunikasi maupun dalam keterampilan proses kelompok.

Di samping ketepatan penggunaan model pembelajaran, kemandirian belajar siswa akan menentukan keberhasilan studi siswa. Pada umumnya siswa belum mampu secara mandiri untuk menemukan, mengenal, merinci hal-hal yang berlawanan dan menyusun pertanyaan-pertanyaan yang timbul dari masalahnya. Sebab siswa awalnya hanya menurut yang disajikan oleh guru atau masih bergantung pada guru. Keberhasilan belajar tidak boleh hanya mengandalkan kegiatan tatap muka dan tugas terstruktur yang diberikan oleh guru, akan tetapi terletak pada kemandirian belajar. Untuk menyerap dan menghayati pelajaran jelas telah diperlukan sikap dan kesediaan untuk mandiri, sehingga sikap 
kemandirian belajar menjadi faktor penentu apakah siswa mampu menghadapi tantangan atau tidak. Kemandirian belajar adalah bagian penting dalam matematika dan pendidikan matematika. Melalui kemandirian belajar, siswa dapat belajar aktif, yang didorong oleh niat atau motif untuk menguasai sesuatu kompetensi guna mengatasi suatu masalah, dan dibangun dengan bekal pengetahuan dan kompetensi yang telah dimiliki (Haris Mudjiman, 2011: 9).

Penelitian ini didukung oleh beberapa hasil penelitian yang dilakukan oleh Sri Wahyuni (2009:64), yang hasil penelitiannya mengatakan bahwa prestasi belajar matematika siswa dengan model pembelajaran konvensional tidak lebih baik daripada prestasi belajar matematika siswa dengan model pembelajaran berbasis masalah. Ini juga sesuai dengan penelitian yang dilakukan oleh Yuli Irfan Aliurido (2008:85), yang mmengatakan bahwa prestasi belajar matematika siswa dengan model pembelajaran tradisional (konvensional) tidak lebih baik dibandingkan dengan prestasi belajar matematika siswa dengan model group investigation, penelitian yang terkait yang dilakukan Rizqi Tresnaningsih (2009: 100) yang hasil penelitiannya mengatakan model pembelajaran problem based learning menghasilkan prestasi yang lebih baik dari pada diskusi.

Penelitian ini bertujuan untuk mengetahui: (1) manakah yang memberikan prestasi belajar matematika lebih baik, antara model problem based learnig (PBL), model pembelajaran kooperatif tipe group investigation (GI), atau model pembelajaran klasikal dengan pendekatan saintifik. (2) manakah yang mempunyai prestasi belajar matematika lebih baik, antara siswa yang memiliki kemandirian belajar tinggi, sedang atau rendah. (3) pada masing-masing kategori model pembelajaran, manakah yang mempunyai prestasi belajar matematika lebih baik, siswa yang memiliki kemandirian belajar tinggi, sedang, atau rendah. (4) pada masing-masing tingkat kemandirian belajar, manakah yang menghasilkan prestasi belajar matematika lebih baik, antara model pembelajaran problem based learnig (PBL), model pembelajaran kooperatif tipe group investigation (GI), atau model pembelajaran klasikal dengan pendekatan saintifik.

\section{METODE PENELITIAN}

Penelitian ini telah dilaksanakan di SMA Negeri dan swasta di Kabupaten Lombok timur pada semester ganjil tahun pelajaran 2014/2015. Jenis penelitian adalah penelitian eksperimental semu (quasi experimental research) dengan rancangan faktorial $3 \times 3$. Populasi dalam penelitian ini adalah seluruh siswa kelas X1 SMA Negeri Kabupaten Lombok timur pada semester ganjil tahun pelajaran 2014/2015. Sampel penelitian sebanyak 282 siswa yang terdiri dari 92 siswa sebagai kelompok eksperimen 1 yang diterapkan model pembelajaran PBL dengan pendekatan saintifik, 94 siswa sebagai kelompok eksperimen 2 yang diterapkan model pembelajaran kooperatif tipe GI dengan pendekatan saintifik, dan 96 siswa dari kelompok eksperimen 3 yang diterapkan model pembelajaran klasikal dengan pendekatan saintifik. Variabel dalam penelitian ini terbagi menjadi dua, yaitu variabel terikat dan variabel bebas. Variabel terikat dalam penelitian ini adalah prestasi belajar matematika pada materi peluang, sedangkan variabel bebas dalam peneletian ini adalah model pembelajaran (PB, GI, dan Klasikal) dengan pendekatan saintifik dan kemandirian belajar (tinggi, sedag, rendah).

Teknik pengumpulan data menggunakan metode dokumentasi, metode angket, dan metode tes. Instrumen penelitian terdiri atas angket kemandirian belajar dan tes prestasi belajar matematika pada materi peluang. Data kemampuan awal prestasi belajar matematika siswa diperoleh dari nilai mid pada kelas eksperimen. Sebelum melakukan eksperimen, dilakukan uji normalitas, homogenitas, dan uji keseimbangan terhadap data kemampuan awal matematika menggunakan analisis variansi satu jalan dengan sel tak sama, sedangkan untuk data prestasi belajar matematika dianalisis menggunakan analisis variansi dua jalan dengan sel tak sama setelah dilakukan uji normalitas dan homogenitas. Uji normalitas untuk data kemampuan awal dan data prestasi belajar dilakukan menggunakan metode Lilliefors dan uji homogenitas variansi populasi menggunakan metode Bartlett. Uji hipotesis menggunakan analisis variansi dua jalan dengan sel tak sama yang dilanjutkan dengan uji komparasi ganda dengan metode Scheffe' jika hipotesis nol ditolak. 


\section{HASIL PENELITIAN DAN PEMBAHASAN}

Hasil uji prasyarat pada data kemampuan awal dan prestasi belajar menyimpulkan bahwa semua sampel berasal dari populasi yang berdistribusi normal dan populasi-populasi mempunyai variansi yang sama. Hal ini ditunjukkan pada hasil perhitungan uji normalitas pada data kemampuan awal dan prestasi belajar. Pada data kemampuan awal, hasil perhitungan uji normalitas kelompok model pembelajaran (PBL, GI, dan Klasikal) dengan pendekatan saintifik menyimpulkan bahwa semua $\mathrm{H}_{0}$ diterima, sehingga sampel berasal dari populasi yang berdistribusi normal dan hasil perhitungan uji homogenitas pada kelompok model pembelajaran (PBL,GI, dan Klasikal) dengan pendekatan saintifik juga menyimpulkan bahwa semua $\mathrm{H}_{0}$ diterima, sehingga sampel berasal dari populasi yang homogen. Pada data prestasi belajar matematika, hasil uji normalitas kelompok model pembelajaran (PBL, GI, dan Klasikal) dengan pendekatan saintifik dan kelompok angket kemandirian belajar (tinggi, sedang, rendah) menyimpulkan bahwa semua $\mathrm{H}_{0}$ diterima, sehingga sampel berasal dari populasi yang berdistribusi normal dan hasil perhitungan uji homogenitas pada kelompok model pembelajaran (PBL, GI, dan Klasikal) dengan pendekatan saintifik dan kelompok kemandirian belajar (tinggi, sedang, dan rendah) juga menyimpulkan bahwa semua $\mathrm{H}_{0}$ diterima, sehingga sampel berasal dari populasi yang homogen. Pada data kemampuan awal dilakukan uji keseimbangan antar kelompok model pembelajaran untuk mengetahui apakah populasi antar kelompok model pembelajaran PBL dengan pendekatan saintifik, model pembelajaran kooperatif tipe GI dengan pendekatan saintifik, dan model pembelajaran klasikal dengan pendekatan saintifik mempunyai kemampuan matematika yang sama. Berdasarkan hasil uji keseimbangan, disimpulkan bahwa sampel dari populasi kelompok model pembelajaran (PBL, GI, dan Klasikal) dengan pendekatan saintifik dalam keadaan seimbang.

Selanjutnya, dilakukan uji anava dua jalan dengan sel tak sama pada data prestasi belajar. Rangkuman anava dua jalan dengan sel tak sama disajikan pada Tabel 1.
Tabel 1. Rangkuman Analisis Variansi Dua Jalan dengan Sel Tak Sama

\begin{tabular}{|l|l|l|l|l|l|l|}
\hline Sumber & JK & dk & RK & Fobs & Ftabel & Kesimpulan \\
\hline $\begin{array}{l}\text { Model } \\
\text { Pembelajaran } \\
\text { (A) }\end{array}$ & 3717.31 & 2 & 1858.65 & 9.4386 & 3.0000 & $\mathrm{H}_{0 \mathrm{~A}}$ ditolak \\
\hline $\begin{array}{l}\text { kemandirian } \\
\text { Belajar (B) }\end{array}$ & 403.64 & 2 & 201.82 & 1.0249 & 3.0000 & $\begin{array}{l}\mathrm{H}_{0 \mathrm{~B}} \\
\text { diterima }\end{array}$ \\
\hline $\begin{array}{l}\text { Interaksi } \\
\text { (AB) }\end{array}$ & 526.66 & 4 & 131.67 & 0.6686 & 2.3700 & $\begin{array}{l}\mathrm{H}_{0 \mathrm{AB}} \\
\text { diterima }\end{array}$ \\
\hline Galat & 3717.31 & 273 & 196.92 & - & - & - \\
\hline Total & 58407.12 & 281 & - & - & - & - \\
\hline
\end{tabular}

Berdasarkan Tabel 1, dapat disimpulkan bahwa: (1) terdapat perbedaan prestasi belajar matematika antar siswa yang mendapat model pembelajaran PBL, GI, dan klasikal dengan pendekatan saintifik; (2) tidak terdapat perbedaan prestasi belajar matematika antar siswa dengan kemandirian belajar tinggi, sedang, dan rendah; (3 ) tidak terdapat interaksi antar model pembelajaran dan kemandirian belajar siswa terhadap prestasi belajar matematika.

Rangkuman rerata marginal pada masingmasing model pembelajaran dan kemandirian belajar siswa disajikan pada Tabel 2 .

Tabel 2. Rerata Marginal dari Model Pembelajaran dan Kemandirian belajar

\begin{tabular}{lcccc}
\hline \multirow{2}{*}{ Model pembelajaran } & \multicolumn{3}{c}{ Kemandirian Belajar } & Rerata \\
\cline { 2 - 4 } PBL-Saintifik & Tinggi & Sedang & Rendah & Marginal \\
GI-Saintifik & 74.22 & 72.20 & 68.00 & 71.61 \\
Klasikal-Saintifik & 68.61 & 68.89 & 69.50 & 68.95 \\
Rerata Marginal & 62.57 & 65.03 & 60.55 & 62.96 \\
\hline
\end{tabular}

Berdasarkan hasil perhitungan anava diperoleh bahwa $\mathrm{H}_{0 \mathrm{~A}}$ ditolak. Oleh karena itu, perlu dilakukan uji komparasi ganda antar baris (antar model pembelajaran). Rangkuman hasil uji komparasi ganda antar baris disajikan pada Tabel 3.

Tabel 3. Rangkuman Hasil Uji Komparasi Ganda antar Baris

\begin{tabular}{|c|c|c|c|c|}
\hline No. & $\mathrm{H}_{0}$ & F $_{\text {hitung }}$ & 2.F $\mathrm{F}_{0.05: 2 \mathrm{n}}$ & $\begin{array}{c}\text { Keputusan } \\
\text { Uji }\end{array}$ \\
\hline 1 & $\begin{array}{c}\mu_{1 .}= \\
\mu_{2 .}\end{array}$ & 1.6708 & 6.00 & $\mathrm{H}_{0}$ diterima \\
\hline 2 & $\begin{array}{c}\mu_{1 .}= \\
\mu_{3 .}\end{array}$ & 17.9443 & 6.00 & $\mathrm{H}_{0}$ ditolak \\
\hline 3 & $\begin{array}{c}\mu_{2 .}= \\
\mu_{3 .}\end{array}$ & 8.6070 & 6.00 & $\mathrm{H}_{0}$ ditolak \\
\hline
\end{tabular}

Berdasarkan Tabel 3 dan rerata marginal pada Tabel 2, dapat disimpulkan bahwa model pembelajaran kooperatif tipe PBL dan GI dengan pendekatan saintifik menghasilkan prestasi belajar lebih baik daripada model pembelajaran klasikal dengan pendekatan saintifik, sedangkan model pembelajaran kooperatif tipe PBL dengan 
pendekatan saintifik menghasilkan prestasi belajar yang sama baiknya dengan model pembelajaran kooperatif tipe GI dengan pendekatan saintifik. Hal ini sesuai dengan hasil penelitian yang dilakukan oleh Eka Wahyu Putra Suminar (2011) yang menyatakan bahwa model pembelajaran PBL memberikan prestasi belajar matematika yang sama baiknya dengan model pembelajaran kooperatif tipe STAD. Di sisi lain model pembelajaran PBL lebih baik dengan model pembelajaran langsung.

\section{KESIMPULAN}

Berdasarkan hasil analisis data, diperoleh kesimpulan sebagai berikut. 1) model pembelajaran kooperatif tipe PBL dan GI dengan pendekatan saintifik menghasilkan prestasi belajar yang lebih baik daripada model pembelajaran klasikal dengan pendekatan saintifik, sedangkan model pembelajaran kooperatif tipe PBL dan GI dengan pendekatan saintifik menghasilkan prestasi belajar yang sama. 2) siswa dengan tingkat kemandirian belajar tinggi, sedang, dan rendah mempunyai prestasi belajar sama. 3) pada masing-masing model pembelajaran, siswa dengan tingkat kemandirian belajar tinggi, sedang, dan rendah mempunyai prestasi belajar yang sama. 4) pada masingmasing tingkat kemandirian belajar, model pembelajaran problem based learning (PBL) dengan pendekatan scientifik dan model pembelajaran kooperatif tipe group investigation (GI) dengan pendekatan scientifik memberikan prestasi belajar matematika yang sama, model pembelajaran problem based learning (PBL) dengan pendekatan scientifik dan model pembelajaran kooperatif tipe group investigation (GI) dengan pendekatan scientifik sama-sama memberikan prestasi belajar matematika yang lebih baik dibandingkan pembelajaran Klasikal dengan pendekatan scientifik.

Berdasarkan kesimpulan hasil penelitian tersebut, penulis memberikan beberapa saran yang dirangkum seperti berikut. 1) mengacu pada hasil penelitian ini, model pembelajaran problem based learning (PBL) dengan pendekatan scientifik dan model pembelajaran kooperatif tipe group investigation (GI) dengan pendekatan scientifik dengan pendekatan saintifik menghasilkan prestasi belajar lebih baik daripada model pembelajaran klasikal dengan pendekatan saintifik. Melihat hal ini, untuk meningkatkan prestasi belajar siswa, guru mata pelajaran matematika disarankan untuk menggunakan salah satu dari kedua model pembelajaran tersebut dalam pembelajaran matematika. 2) sesuai dengan implementasi kurikulum 2013, guru disarankan untuk terus mencoba menerapkan langkah ilmiah 5M pada setiap pembelajaran. Hal ini dirasa perlu, karena pendekatan saintifik memerlukan waktu penerapan yang cukup lama, hingga siswa terbiasa untuk menjalankan proses mengamati, menanya, mencoba, menalar, dan mengkomunikasikan. 3) dalam melaksanakan kegiatan pembelajaran, guru perlumemperhatikan kondisi siswa diantaranya adalah tingkat kemandirianbelajar, motivasi, keaktifan, dan sebagainya. 4) berdasarkan kesimpulan hasil penelitian tersebut, penulis memberikan beberapa saran yang dirangkum seperti berikut. 1) mengacu pada hasil penelitian ini, model pembelajaran problem based learning (PBL) dengan pendekatan scientifik dan model pembelajaran kooperatif tipe group investigation (GI) dengan pendekatan scientifik dengan pendekatan saintifik menghasilkan prestasi belajar lebih baik daripada model pembelajaran klasikal dengan pendekatan saintifik. Melihat hal ini, untuk meningkatkan prestasi belajar siswa, guru mata pelajaran matematika disarankan untuk menggunakan salah satu dari kedua model pembelajaran tersebut dalam pembelajaran matematika.

\section{DAFTAR PUSTAKA}

Badan Nasional Standar Pendidikan. 2013. Laporan Hasil Ujian Nasional 2012/2013. Kementerian Pendidikan dan Kebudayaan.

Davi Apriandi. 2010. Efektifitas Pembelajaran Berbasis Masalah Dan Pembelajaran Kooperatif Bertipe Group Investigation Terhadap Prestasi Belajar Matematika Ditinjau Dari Kecerdasan Majemuk Siswa Kelas Vii Smp Negeri Kota Madiun. Tesis UNS. Tidak dipublikasikan. 
Haris Mudjiman .201. Belajar Mandiri. Surakata: UNS Press

Implementasi. Bandung: Remaja Rosdakarya.

Jamal Makmur Asmani. 2011. Buku Panduan Internalisasi Pendidikan Karakter di Sekolah. Yogyakarta: DIVA Press.

Mulyasa. 2002 Kurikulum Berbasis Kompetensi, Konsep Karaktristik, dan

Rizqi Tresnaningsih. 2010. eksperimentasi pembelajaran berbasis masalah dan diskusi kelas terhadap prestasi belajar matematika siswa kelas $x$ ditinjau dari iq siswa pada materi logika matematika sma negeri kabupaten magetan. Tesis UNS. Tidak dipblikasikan.

Stacey, K. 2011. The pisa view of mathematical literacy in Indonesia. Indo MS J.M.E VOL.2 NO.2 pp 95-126

Sutarto Hadi. 2005. Pendidikan Matematika Realistik. Banjarmasin: Penerbit Tulip. 